\title{
GENDER IDENTITY IN INTERACTION: OVERCOMING HETERONORMATIVITY
}

\author{
LA CONSTRUCCIÓN DE LA IDENTIDAD DE GÉNERO EN \\ INTERACCIÓN: MÁS ALLÁ DE LA HETERONORMATIVIDAD
}

Carmen SANTAMARÍA-GARCÍA

Author / Autora:

Carmen Santamaría-García

Universidad de Alcalá

Alcalá de Henares, Spain

mcarmen.santamaria@uah.es

http://orcid.org/0000-0003-4160-169X

Submitted / Recibido: 20/12/2020

Accepted / Aceptado: 02/04/2021

To cite this article / Para citar este artículo: Santamaría-García, C. (2021). Gender identity in interaction: overcoming heteronormativity. Feminismo/s, 38, 203-229. Women, Sexual Identity and Language [Monographic dossier]. I. Balteiro (Coord.). https://doi.org/10.14198/ fem.2021.38.08

\section{Licence / Licencia:}

This work is licensed under a Creative Commons Attribution 4.0 International.

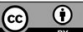

(C) Carmen Santamaría-García

\begin{abstract}
The present article reviews theoretical concepts that can contribute to the analysis of the construction of gender identity in interaction, moving on from heteronormativity, understood as the normalization of heterosexuality as the only, or more, legitimate form of sexuality. Identity is discussed together with the concepts of face, rapport and (im)politeness from a discursive approach (van der Bom $\&$ Mills, 2015). It is argued that gender identity face builds on attributes of both respectability and identity faces with differing strengths and saliency depending on the individuals and the context. Analysis is limited to the construction of hetero and gay male gender identities in interaction with women in academic contexts and draws on data from a corpus of naturally occurring interactions compiled by the author. Gay males seem to differ from hetero males in in their choice of resources for doing face-enhancing positive politeness and rapport with their female colleagues. Despite the limited size of the sample, the study hopes to contribute to a better understanding of the construction of gender identity from a discursive approach.
\end{abstract}

Keywords: Gender; Face; Identity; Rapport; (Im)politeness. 


\section{Resumen}

El presente artículo revisa conceptos teóricos que pueden contribuir al análisis de la construcción de la identidad de género en interacción, más allá de la heteronormatividad, es decir, de la normalización de la heterosexualidad como única forma válida de sexualidad, o al menos la más legítima. El concepto de identidad se explora junto con los conceptos de imagen, conexión (rapport) y (des)cortesía desde un enfoque discursivo (van der Bom \& Mills, 2015). La autora argumenta que la identidad de género se construye en función de los atributos de imagen de respetabilidad y de identidad, con diferentes grados de prominencia y saliencia según los individuos y el contexto. El análisis se limita a la construcción de identidades de género masculino, tanto hetero como gais, en interacción con mujeres y se basa en datos de un corpus de interacción natural recopilado por la autora. Los varones gais de la muestra parecen utilizar diferentes recursos que los varones hetero en la construcción de relaciones cercanas mediante el uso de cortesía positiva, potenciadora de la imagen social de sus compañeras. A pesar del reducido tamaño de la muestra, el estudio espera contribuir a una mejor comprensión de la construcción de la identidad de género desde un enfoque discursivo.

Palabras clave: género; imagen; identidad; rapport; (des)cortesía.

\section{INTRODUCTION}

Feminist linguistics is moving away from the study of gender as if it were contained in discrete linguistic items. Influenced by the work of Judith Butler, gender is seen as performative, that is, constructed in the process of interacting with others and dependent both on the context in which interaction takes place and the assumptions about appropriate behaviour that are seen to be in play (Butler, 1990). As noted by Eckert and McConnellGinet (2003, p. 305) in an elaboration of her ideas, «gender is not a part of one's essence, what one is, but an achievement, what one does» and a set of practices, «through which people construct and claim identities, not simply a system of categorizing people. And gender practices are not only about establishing identities but also about managing social relations».

Traditional approaches to gender have focused on gender difference, considering gender as something that one has, or «part of one's essence» (Mills, 2005, p. 271). Such essentialist views were not only present in research on gender but also featured in traditional work on culture that are currently

Feminismo/s 38, July 2021, 203-229 
challenged: «According to the essentialist view, which will be challenged in a number of respects in the present chapter, culture manifests itself in one's identity, and consequently one's linguistic interpersonal behaviour is regarded as unavoidably driven by one's cultural identity» (Kádár \& Haugh, 2013, p. 231).

However, after what has come to be called the «discourse turn», i.e. the move from the analysis of discrete language categories to a higher discourse level, individuals are no longer approached as coherent and stable entities but as «a range of subject positions, some of which come to the fore in interaction with particular groups of other people; the individual engages with others and is defined and changed by that engagement and contributes to the changes taking place within the community of practice» (Mills, 2003, p. 30).

Third-wave sociolinguistics views styles, rather than variables, as directly associated with identity categories, and explores the contributions of variables to styles. Variation is examined as part of the wider performative system of language and its meaning, as part of the wider meaning system (Eckert, 2012, 2019). Within this approach, gender is examined as constructed in interaction and its study has progressed from «the search for correlations between linguistic units and social categories of speakers to analysis of the gendered significance of ongoing discourse» (Eckert \& McConnell-Ginet, 2003, p. 4, as cited in Mills, 2005, p. 271).

Despite research within this third wave is growing, studies of gender performativity in interaction, portraying speakers who do not conform to heteronormativity and gender binarism, are still scarce. This article aims to provide a theoretical framework that can facilitate the analysis of gender identity construction in interaction, moving beyond heteronormativity. It starts by reviewing the literature that has influenced my perspective on face, identity, rapport, (im)politeness and related concepts, including some of the criticism that has been brought forward by them. Adopting a discursive approach (van der Bom $\&$ Mills, 2015, p. 181), I will argue for the importance of these concepts in the discursive construction of gender identity in interaction and for the need to have them incorporated into current research in gender discourse.

Analysis of a sample of extracts of authentic data from interaction follows, focusing on the language choices that seem to contribute to the construction

Feminismo/s 38, July 2021, 203-229 
of interactants' male gender identities. The sample includes hetero and gay male professors of the same age band in interaction with female lecturers, a lower rank in the academic scale. A qualitative, sacksian tradition of analysis has been followed (Peräkylä, 2004), with a focus on gender practices (Mills, 2003 and 2005). Following House (2018), qualitative and quantitative analysis research methods are not seen as mutually exclusive but as located along a continuum.

Turning to the qualitative end of the continuum and drawing on House's (2018, p. 7) terms, the basic function of the qualitative research presented here is, «to Understand Human Behaviour» rather than «explain» it, «with hypotheses evolving gradually through interpretive findings of repeated patterns». My analysis draws on the concepts in the theoretical framework in order to facilitate understanding of the processes in the performative construction of gender. No objectivity is claimed, as «The notions of 'Understanding' and 'Interpreting' in qualitative research suggest that 'objectivity' is neither important nor indeed possible» (House, 2018, p. 7).

The analysis presented is, thus, neither data-driven nor hypothesis-testing and the corpus has been used in what Partington et al. (2013, p. 240) describe as the most frequent use in (im)politeness studies «a resource for examples». As House (2018) brilliantly explains, research in pragmatics faces a fundamental conflict between its goals and the means to achieve them. It aims at generalizable and systematic commonalities but «every single interaction is a separate linguistic action, a 'case' which features particular biographical backgrounds, particular interactional histories, particular personal competencies and preparedness to cooperate with others in a particular situation». At the same time, a multiplicity of other situation-specific factors can influence the interactional process and «All this clearly defies generalization» House (2018, p. 4).

House quotes Chafe and his «imaginatively expanded vision» as a perspective that can provide us with causal explanations for whatever we want to find out: «Understanding of whatever kind is the ability, through imagination, to relate limited, particular, concrete observations to larger, more encompassing, more stable schemas within which the particular experiences fit» (Chafe, 1994, p. 10, as cited in House, 2018, p. 4). I hope this article manages to relate the author's observations in the analysis to larger, more

Feminismo/s 38, July 2021, 203-229 
encompassing and stable schemas within which the particular experiences contained in the samples fit.

Analysis of the interaction sequences in the corpus have led to hypothesis formulation evolving gradually through interpretive findings of repeated patterns, following House (2018, p. 7). The working hypothesis, based also on the author's participant observation in academic life and the theoretical framework compiled, is that gender identity face is performative and builds on attributes of both respectability and identity faces for the construction of gender identities, with differing strengths or saliency depending on the individuals and the context. Hetero and gay males are expected to portray different gender identities in their interaction with female colleagues, which may result in different types of relationships. Analysis will attempt to understand why this could be so.

The extracts are part of a corpus collected by the author along twenty-five years of academic life, which contains ca. 500.000 words in different types of interactive texts: spoken texts (face to face and telephone conversations) and written texts from e-mail exchanges) in English and Spanish languages. The author was a participant in most of the communicative events, a practice recommended in current research (Partington et al., 2013, p. 241), which prevents the risk of context neglect and allows for first-hand knowledge of contextual cues. The corpus also contains some interactive sequences contributed by family, friends and colleagues, which are complemented by contextual information. Permission has been granted to use anonymised examples for research.

Whenever possible, interactants have also been interviewed in order to check their interpretation of what had happened in interaction, trying to collect «different types of naturally occurring data» (Grainger \& Mills, 2016 , p. 28). Participants' interaction is analysed by focusing on their orientation to gender identity, as discursively performed. The article ends with some concluding remarks on the usefulness of the theoretical framework presented and its potential contribution to a better understanding of gender identity construction in language. 


\section{THEORETICAL FRAMEWORK}

The following sections contain a review of research on face and identity, rapport and (im)politeness, with a view to provide a theoretical framework for this study, based on concepts that may contribute to the analysis of gender identity construction in interaction.

\subsection{Face and identity}

Face has received a lot of attention by scholars in the field of (im)politeness, especially since Brown and Levinson had it incorporated in their formulation of politeness theory. Despite its conceptual proximity to face, «identity has not constituted a main focus of (im)politeness scholars until recently» (Garcés-Conejos Blitvich \& Sifianou, 2017, p. 227), with the work by SpencerOatey as an example of the progressive incorporation of identity aspects into face theory. Brown and Levinson defined face as «the public self-image that every member wants to claim for himself» (Brown \& Levinson, 1987, p. 61), borrowing the term from Goffman, who had given this definition for face:

The term face may be defined as the positive social value a person effectively claims for himself by the line others assume he has taken during a particular contact. Face is an image of self delineated in terms of approved social attributes -albeit an image that others may share, as when a person makes a good showing for his profession or religion by making a good showing for himself (Goffman, 1967, p. 5)

In Goffman's definition, face is seen as the result of speakers' presentation and its construction by others, as Dippold $(2009$, p. 3) observes: «[...] face is a conglomerate of the self-image speakers want to present to the outside world and the image that is constructed of them by others». However, Brown and Levinson seem to have ignored the important role played by interactants in the construction of face and to have interpreted the concept as an individual's feeling of self-worth or self image (Thomas, 1995, p. 169, as cited in Bousfield, 2008 , p. 33). This individualistic conceptualisation has met with ample criticism and triggered a return to the original concept by Goffman, considering face as «both constructed and projected by speakers and attributed to them» (Dippold, 2009, p. 6). In a more radical view, such as Terkourafi's (2008), face is either enhanced or threatened purely in interaction:

Feminismo/s 38, July 2021, 203-229 
Individuals alone do not 'have' face and cannot 'gain' or 'lose' face. Rather [face] is grounded in the interactional dyad. Without an Other to whom they may be directed, face concerns cannot arise. The moment an Other enters the Self's perceptual field creating the possibility of to approach or to withdraw, that is the moment when face concerns prototypically arise. To adapt a well known expression, face is 'in the eye of the beholder' (Terkourafi, 2008, p. 52).

For Terkourafi, face is either enhanced ('constituted' in her terms) or damaged, there is no middle ground, and this happens over multiple turns in interaction «in the flow of events in the encounter», using Goffman's (1967, p. 7) wording. Although accepting this, I cannot agree, echoing Bousfield (2008, p. 39) «that the individual interactant does not bring something concerning their own face to the interaction». As he observes, "After all, surely we approach interactions with expectations as to how we would like our face(s) to be constituted. Such expectations of how face should be constituted are necessarily internal» (Bousfield, 2008, p. 39). Therefore, instead of adopting a purely 'external' notion of face, I also prefer to view face «as internally expected and externally realised in interaction» (Bousfield, 2008, p. 41).

Face expectations are based on feelings of self-worth that can be further described by reference to other attributes. Spencer-Oatey makes a distinction between a situation-specific identity face and a pan-situational respectability face. Identity face «is a situation-specific face sensitivity, that is highly vulnerable» (Spencer-Oatey, 2005, p. 103) and corresponds fairly closely to Goffman's conception of face, while respectability face refers to «the prestige, honor or 'good name' that a person or social group holds and claims within a (broader) community» (Spencer-Oatey, 2005, p. 102). She observes that, according to Goffman, claims to identity face occur in specific social encounters/interactions and reflect people's social values in relation to specific social attributes. In addition, she takes identity face to include claims to social group membership (Spencer-Oatey, 2005, p. 103).

On the other hand, respectability face, reflects the relative weights attributed to: «biographical variables (e.g., age, sex), relational attributes (e.g., marriage ties), social status indicators (e.g., educational attainment, occupational status, wealth), formal title/position/rank, personal reputation (moral or amoral) and integrity» (Ho, 1994: 276, as cited in Spencer-Oatey, 2005, 
p. 103) and are cultural constructs, as «different cultures attach varying degrees of importance to different attributes, so the bases of respectability face could be very different in different nations and social groups» (SpencerOatey, 2005, p. 103).

For Spencer-Oatey, «it is identity face rather than respectability face that is threatened or enhanced in specific interactional encounters» (2005, p. 103). I cannot agree with this, as it seems that respectability face can be threatened when the attributes on which it is based are ignored or attacked. For instance, addressing a senior member of a board without the degree of formality expected could amount to a judgment of lack of respect, resulting in face threat.

In my opinion, individuals may have expectations related to both respectability and identity faces that can be either constitued (enhanced) in interaction or not. This also seems to be the interpretation in Matsumoto's understanding that «face is intimately bound up with showing recognition of one's relative position in the communicative context and with the maintenance of the social ranking order» (1988, p. 415). When face expectations are not met with the expected degree of face enhancement, negative feelings may arise, which may even end up in conflict or aggression. As Bousfield observes «[...] face expectations not matching face reality may well result, amongst other things, in the communication, manipulation or management of impoliteness or aggression, linguistic or otherwise» (2008, p. 40).

Identity face can be further explored by recurring to psychological models of identity. Spencer-Oatey draws on Simon's self-aspect model of identity and proposes that people's claims to identity face are based on the positive social values that they associate with their various self-aspects, which are defined as «cognitive categories or concepts that serve to process and organise information about oneself» (Spencer-Oatey, 2005, p. 104). She turns to Simon for their illustration:

[...] self aspects can refer, inter alia, to generalized psychological characteristics or traits (e.g., introverted), physical features (e.g., red hair), roles (e.g., father), abilities (e.g., bilingual), tastes (e.g., preference for red wines), attitudes (e.g., against the death penalty), behaviours (e.g., I work a lot) and explicit group or category membership (e.g., member of the Communist Party) (Spencer-Oatey, 2005, p. 104)

Feminismo/s 38, July 2021, 203-229 
It is important to note that some of these self-aspects may be more important than others and face sensitivities develop around those aspects that are more important: «People are likely to vary in the importance they attach to all of the various qualities, both because of their personal value systems and also because of the context» (Spencer-Oatey, 2005, p. 104). Face sensitivities can operate in foreground or background modes but are never absent. «Like computer anti-virus programs, they may run unobtrusively for much of the time, but the moment a problem arises, they capture the user's attention» (Spencer-Oatey, 2007, p. 642). These sensitivities occur across a range of elements, including the following: «[...] bodily features and control (e.g., skin blemishes, burping), possessions and belongings (material and affiliative), performance/skills (e.g., musical performance), social behavior (e.g., gift giving, rude gestures), and verbal behavior (e.g., wording of illocutionary acts, stylistic choice)» (Spencer-Oatey, 2005, p. 104). People may perceive a threat to their face «if these self-aspect sensitivities are challenged or undermined» and «conversely, if their sensitivities are ingratiated appropriately, people may perceive an enhancement of their identity face» (Spencer-Oatey, 2005, p. 104).

The concept of face seems of special relevance in the study of gender in both respectability and identity aspects. Regarding respectability face, we can explore the influence of sex and sexual orientation in the relational and status attributes intervening in the construction of gender. For instance, a heterosexual female may be construed as a wife of a man and be ascribed a particular set of relational attributes operating in a particular community of practice, such as «a respected Mrs.», enjoying a characteristic status, or as a «boring housewife», lacking that respect.

On the other hand, homosexual females in a same-sex relationship will most probably be assigned different attributes. They could be construed as the «more masculine» partners or the «more feminine» ones, for instance, following stereotyped attributes, as discussed by Mahdawi (2016) in The Guardian.

Heterosexual males may be ascribed relational attributes of power and respect in some contexts or lack of them in different settings and circumstances. Gay males may still need an extra effort in order to be ascribed 
attributes of power and respect, and even be challenged in their attempts to be entitled to them in homophobic contexts.

Regarding identity face sensitivities, it can be relevant to observe different types of gender sensitivities that can be either enhanced or challenged in discourse. A particular concern with the following features can index and constitute gender: bodily features and control situations (e.g., breast size, menstruation, incontinence), possessions and belongings (e.g., luxury objects and affiliative relations), performance/skills (e.g., good professional, skilled professional, sportsperson, artist, etc.), social behavior (e.g., gift giving, rude/sweet gestures), and verbal behavior (e.g., stylistic choice, pitch and intonation).

It will also be essential to identify which particular type of face is being foregrounded by interactants at a particular moment, as individuals can behave very differently depending on the context. Power is a very relevant factor accounting for variation, as «often individuals behave very differently depending on whether they are with equals or with those to whom they appear to be subservient» (Scott, 1990, as cited in Grainger \& Mills, 2016, p. 13). As gender difference often entails power difference, this observation seems very pertinent for gender studies.

Claims to face are not only individual and «can also be a group-based phenomenon, and apply to any group that a person is a member of and is concerned about» (Spencer-Oatey, 2005, p. 106), from small groups (one's family), to larger groups (ethnic, religious or nationality group). Following Simon (2004), Spencer-Oatey takes group face sensitivities to refer to «the self-aspects of a person's identity that are derived from membership in a collective or group, and not to refer to the identity of a group as a sui generis entity» (Spencer-Oatey, 2005, p. 107). She mentions other psychologists (e.g., Markus \& Kitayama, 1991) who distinguish between independent and interdependent self-construals.

Consideration of group face sensitivities can be especially relevant in the study of gender, as discourse can either enhance or threaten the collective face of individuals, e.g. women's collective face or gay's collective face. The need for more theoretical discussion and empirical research on face and identity is noted by Garcés-Conejos Blitvich \& Sifianou (2017). They claim that «(im)politeness and aggression play a strong role in the construction of

Feminismo/s 38, July 2021, 203-229 
the out-group in processes of othering» (2017, p. 228), processes that often intervene in gender-related discursive othering.

\subsection{Rapport}

Rapport is defined as «the relative harmony and smoothness of relations between people» (Spencer-Oatey, 2005, p. 96). It is based on a subjective perception and consequently, different people may have different perceptions on the need and best ways for rapport management, understood as «the management (or mismanagement) of relations between people» (SpencerOatey, 2005, p. 96). Differing types of rapport orientations can be observed amongst people:

[...] a rapport-enhancement orientation, (a desire to strengthen or enhance harmonious relations between the interlocutors), a rapport maintenance orientation (a desire to maintain or protect harmonious relations), a rapport-neglect orientation (a lack of concern or interest in the quality of relations, perhaps because of a focus on self), or a rapport-challenge orientation (a desire to challenge or impair harmonious relations (SpencerOatey, 2005, p. 96).

It seems difficult to use these four levels of distinction in the analysis of naturally occurring interaction and, for this reason, I will rather adhere to Terkourafi's distinction and see face as either constituted (enhanced) or damaged in interaction (2008, p. 7). I agree with Spencer-Oatey, however, in the understanding that people make dynamic judgments regarding rapport and these judgments, which may be «conscious or otherwise», are based on the assessment of «behavioural expectations, face sensitivities and interactional wants» (Spencer-Oatey, 2005, p. 96). They will be briefly considered in turn, as constituting the bases of (im)politeness judgements.

Behavioural expectations, and the (im)politeness judgements derived from them, can be based on the following: «contractual/legal agreements and requirements, [...] role specifications, [...] behavioural conventions, norms and protocols, [...] and interactional principles» (Spencer-Oatey, 2005, pp. 98-99). They are interconnected and can inform peoples' beliefs about behaviour. These elements can intervene in behavioural expectations about gender and can have consequences for rapport. A marriage agreement, a particular family role, conventions about the expected behaviour of wives, husbands, 
same-sex partners, work colleagues, friends, etc. can all influence individuals' expectations and their judgements on (im)politeness.

Face sensitivities, as described above in the discussion of the concept of face, can also influence (im)politeness beliefs in relation to gender and have consequences for rapport. Gender-related self-aspect sensitivities can be challenged or enhanced, and be perceived as salient, especially at moments of interpersonal crisis (Mills, 2005, p. 264). Bodily aspect and control, (e.g., breast size, menstruation, incontinence), possessions and belongings (e.g., luxury objects and affiliative relations), performance/skills (e.g., dancing, sports), social behavior (e.g., gift giving, rude/sweet gestures), and verbal behavior (e.g., stylistic choice, pitch and intonation) can be the source of tension and used in the discursive construction of gender.

Interactional wants refer to relational and transactional goals. They can be combined with similar weight in interaction but there are situations in which participants may show a very specific orientation to a particular type of interactional goals and this can affect peoples' judgments. Evaluation of behaviour can be negative if «judged to be too strategic» (Spencer-Oatey, 2005, p. 107). For instance, in a work environment, someone who goes direct to the point, giving priority to the transactional, can be perceived as neglecting the relational.

On the other hand, too much attention on the relational can be considered invasive or too strategic with a view to get a particular goal in the speaker's benefit. Interactional goals can play an important role in the construction of gender, as individuals can be judged according to expected behaviours in relational or transactional goals according to gender. For instance, individuals' behaviour can be negatively judged as flirtatious (too much relational) in interaction with individuals of the opposite sex for a strategic end.

\section{3. (Im)politeness}

Politeness research has gone through different stages since the early formulation of politeness theory by Brown and Levinson, understood as «a concern with indicating closeness or distance from the interlocutor» (Grainger $\&$ Mills, 2016, p. 4). Brown \& Levinson (1987, p. 70) distinguished between two types of politeness, namely, positive and negative politeness. Positive 
politeness is oriented to closeness between speaker and hearer, while negative politeness is concerned with not imposing on the other person, showing respect and deference.

A growing feeling of dissatisfaction with many aspects of their framework, such as an individualistic approach to face or their universalistic statements, led to a discursive approach to the analysis of (im)politeness, which is not simply a critique but a mode of analysis (van der Bom \& Mills, 2015, p. 181). The discursive approach incorporates the element of power and its impact on relations:

The discursive approach, broadly speaking, focuses on the way that discourses inform what speakers think is possible to say, how they view their relations with others and with their communities, and how power impacts on these relations. Rather than starting with an analyst's sense of what politeness consists of, there is a tendency for analyses to be local, context-focused, and qualitative. These analyses are often focused on misunderstanding, ambiguity and the potential for interpreting an utterance as polite or impolite, rather than assuming that politeness is inherent in words themselves (van der Bom \& Mills, 2015, p. 180).

Therefore, consideration of context is of paramount importance, including the ideologies that can determine the possible meanings and interpretations of politeness (Grainger \& Mills, 2016, p. 8). (Im)Politeness is not inherent in utterances but depend on interactants' judgements, which are in turn, shaped by society values:

Politeness and impoliteness are only those that are judged by interactants to be so, but interactants do not make these judgements in a vacuum. [...] through dint of being used within particular contexts, they [particular forms] will begin to pick up particular values and associations and these used will begin to appear conventional or common-sense (Grainger $\&$ Mills, 2016, p. 9).

This new approach entails a different methodology of analysis, as utterances cannot be analysed without their context of occurrence nor can their uptake be ignored. A discursive approach to politeness «would analyse an utterance in a particular context and analyse the way that the utterance seems to be functioning, the way it is responded to by the interactants and whether it is treated as polite or impolite» (Grainger \& Mills, 2016, p. 9). A discursive

Feminismo/s 38, July 2021, 203-229 
approach is interested in the description of linguistic ideologies, defined as «[...] those beliefs about language that entail evaluations, both positive and negative, about particular language styles or usage» (Grainger \& Mills, 2016, p. 11). As (im)politeness consists of judgement and evaluation of other's utterances and behaviour, it is most likely to be informed by interactants' linguistic ideologies of what is (in)appropriate.

A discursive approach is also of special interest and relevance for the exploration of gender, as it will analyse interactants' judgements of what is considered gender appropriate. Gender appropriateness draws on judgements on behaviours and linguistic features that seem to be stereotypically associated with masculinity or femininity, i.e. indexing masculine or feminine gender behaviour. For instance, linguistic features that seem to be associated with masculinity, and hence with power, are: «the use of direct assertions rather than indirectness; swearing; unmitigated statements and expressions of negative opinion; face-threatening acts in general; verbal wit and humour, non-emotional language» (Mills, 2005, p. 273). As McElhinny has demonstrated, many of these features are also assumed to be indicative of professionalism (McElhinny, 1998, as cited in Mills, 2005, p. 273).

On the other hand, feminine gender identity behaviour has been constructed around notions of «'nice', supportive, co-operative behavior» (Mills, 2005, p. 263), «indirecteness» (Mills, 2005, p. 272), and associated with politeness, self-effacement, weakness, vulnerability, and friendliness (Mills, 2003, p. 203). When considering the distinction between positive and negative politeness, «Women's linguistic behavior is often characterised as being concerned with co-operation (more positively polite than men) and avoidance of conflict (more negatively polite than men) (Mills, 2003, p. 203).

However, as Mills notes, feminists have contested stereotypes of gender for many years now and many of these stereotypes have themselves been changed because of the changes in women's participation in the public sphere: "We can therefore no longer assume that everyone has the same 'take' on a stereotype, or that they share assumptions with others about what a particular stereotype consists of, or even that they accept stereotypes at face value rather than, for example, ridiculing them» (Mills, 2003, p. 203).

Research on politeness incorporated the study of impoliteness in its own right with the turn of the century. Impoliteness describes «any type of

Feminismo/s 38, July 2021, 203-229 
linguistic behaviour which is assessed as intending to threaten the hearer's face or social identity, or as transgressing the hypothesized Community of Practice's norms of appropriacy» (Mills, 2005, p. 268). Instead of seeing impoliteness as the opposite of politeness, there is agreement now that impoliteness does different interactional work than politeness, as discussed by Beebe (1995, p. 161) or Mills (2005, p. 264). Beebe claims that motivated or intentional impoliteness is not failure to be polite and it can achieve certain aims in a conversation, «firstly, to get power and secondly, to give vent to negative feelings» (Beebe, 1995, p. 154, as cited in Mills, 2005, p. 267).

The observation that motivated impoliteness can give power seems to be of high relevance for the analysis of gender construction, as it can be used as a resource for domination in interaction. However, impoliteness is not simply a question of making statements which are offensive, but also of displaying to others an assessment of one's social standing (Mills, 2005, pp. 267-268). Therefore, a range of behaviours that do not include offensive language can also be considered impolite if showing, for instance, domination, lack of respect or unsupportive attitudes. In more technical terms and using Spencer-Oatey's concepts discussed above, an action can be considered to be impolite when it challenges behavioural expectations of what is appropriate, interactants' face sensitivities and the interactional needs that are expected in a particular situation.

The study of the relationship between gender and impoliteness can throw light into the complexities of gender construction in interaction. In her analysis of the role that gender plays in the attribution of impoliteness, Mills proposes «a model of impoliteness which is performative and dependent upon contextual judgements» (Mills, 2005, pp. 263-264). Impoliteness and gender do not pre-exist interactions but «are constructed in slightly different ways in each interaction depending on assessments of the interactional history of particular Communities of Practice, and the stereotypes of both politeness and gender which are constituted within the course of the interaction itself» (Mills, 2005, p. 263).

Our linguistic behaviour is judged in relation to our past behaviour and to the type of behaviour that is expected and considered appropriate in a particular situation. Mills argues convincingly for the influence of stereotypes

Feminismo/s 38, July 2021, 203-229 
in what is perceived to be gender-appropriate behaviour in the judgments made by interactants on the appropriateness of others' actions.

If we consider gender to be something that we perform in each interaction, and if our linguistic behaviour is judged in relation to our past behaviour and to the type of behaviour which is considered appropriate for the group, then middle class white women choosing to speak in indirect ways may well achieve their ends, that is showing concern for the Community of Practice without bringing about conflict, even though others may well judge their behaviour to be indicative of powerlessness [...]. Other women may well choose to use more direct language to signal their independence and professionalism, but may be judged as aggressive and impolite (Mills, 2005, p. 276).

Mismatching judgements may arise from stereotypes of gender-appropriate behaviour. If one of the participants in a Community of Practice assumes that females should be submissive, linguistically and interactionally, then any form of assertive or «masculine» linguistic behaviour may be interpreted as impolite or inappropriate.

In all interaction, individuals are working out their gendered identity and their position within a community of practice, as well as communicating with others, and politeness and impoliteness play a key role in presenting and producing a particular type of identity, and negotiating a position in the community of practice. Judging someone's utterance to be polite or impolite is also making an assessment of them as individuals. Deciding to be polite or impolite is a crucial part of constructing one's own sense of identity as 'nice', 'considerate', 'assertive', or 'tough', and assessing one's role in relation to other members of a group (Mills, 2003, p. 9).

It seems of utmost importance, then, to consider gender as a factor contributing to the assessment of an act as (im)polite, and explore the consequences of such assessments on individuals and communities of practice (Mills, 2005, p. 265). Beliefs about gender, emanating from society and permeating through smaller communities of practice, can be responsible for our assessments on speakers' intentions as impolite. Kádár and Haugh (2013, p. 64) suggest that normative understandings can be situated relative to any social unit, «ranging from dyads and relatively closed relational networks (such as families or groups of close friends), through to larger and thus inevitably more diffuse societal or cultural groups».

Feminismo/s 38, July 2021, 203-229 


\section{ANALYSIS OF GENDER IDENTITY IN INTERACTION}

The concepts discussed in the previous sections are of vital importance when considering the construction of gender identity in interaction. The analysis in this section tries to prove the hypothesis that gender identity face builds on attributes of both respectability and identity faces, with differing strengths or saliency depending on the individuals and the context. Individuals in the sample are expected to portray different gender identities in different interactions and the analysis will attempt to understand why this could be so.

A discursive approach to data analysis has been adopted, which «requires that we analyse talk in context and that we approach meaning as a social and interactional achievement» (Grainger \& Mills, 2016, p. 29). The analysis of impoliteness draws on the reconstruction of what the speakers' intentions are supposed to have been (Mills, 2005, p. 265). Therefore, hypothesizing on intention is essential to assessing an act as impolite (Mills, 2005, p. 266). When I have been involved as a participant in interaction, the interpretations discussed originated in the participant, not the analyst, following the approach adopted in O'Driscoll (2017, p. 488). Data have been collected from interaction in different academic contexts.

The fragments of interaction to be analysed and discussed below have been chosen as illustrative of different constructions of respectability and identity faces for hetero and non-hetero identities of male professors in the same age band in interaction with female lecturers, a lower rank in the academic scale. In the first fragment we will see an example of a hetero male professor constructing a position of power in a group of women colleagues. The fragment contrasts with the second one, in which the same man shows alignment with one of the female colleagues in the previous interaction.

The third fragment portrays a hetero male professor who chooses to construct a powerless position in interaction with a female colleague. The fragment contrasts with the fourth one, in which the same man builds a more equal relationship with the same female colleague. The fifth and sixth extracts illustrate different positions by a non-hetero male professor in interaction with a female colleague, a position of camaraderie and affect first and a more authoritative stance in a different context in extract 6 . The last extract, 
(number 7), further illustrates the use of face-enhancing affective language by a gay male professor in interaction with a female colleague.

The first extract to be discussed happened during interaction at a meeting by a group of university teachers. A complaint was put forward by a group of four female teachers in their early forties about what they considered to be too much familiarity and lack of respect in students' electronic mail correspondence. After several comments, providing illustration of the situation with examples, one of the teachers (a female in her forties) suggested the need for a brief style guide, which could be written and distributed amongst teachers and students. The more senior teacher in the group, who happened to be a male professor in his fifties, said that he had not experienced anything similar and therefore, did not see the need for such an initiative. This is the interactional extract, which was not recorded but scripted, right after the event happened:

Extract 1.

Female teacher: Podíamos escribir una guía de estilo y pedirles que la siguieran. ¿Qué os parece?

We could write a style guide and ask them to follow it. What do you think?

Male teacher: A mí no me ha pasado nunca nada de eso. No veo ninguna necesidad.

Nothing like that has ever happened to me. I don't see the need.

Female teacher: Quizá porque eres un hombre, a ti no te dicen las mismas cosas.

Probably because you are a man, they don't tell you the same things.

(Male teacher says nothing else and the topic is abandoned, as someone else introduces another topic).

In this extract, the male teacher chose not to adhere to neither his colleagues' complaints nor the proposal for a style guide. Once the meeting was over and he had left the room, the woman who had suggested the need for a style guide said that she felt they could have argued further, to which another woman replied that it would not be very practical («No es práctico»), seeming to imply that it was a difficult enterprise with no guarantees to succeed, as their male colleague was not supporting the idea. In this case, a man managed to «other» a group of four women who, as a result, chose not to continue with a claim for action in response to a problem they had. 
The gender identity construction of the man in this extract can be characterized by attributes of power, authority, professional competence, assertiveness and individualism, at least in a higher degree than his female colleagues. He said he had not had a problem like the one reported by his colleagues and, hence, he saw no need for action. His female colleague in the extract can be characterized by a lower degree of power and assertiveness and a somewhat more collective orientation, as she was trying to solve a problem that was affecting several colleagues. She makes use of positive politeness by requesting her colleagues' opinion: «What do you think?»

Due to his seniority, position and authority as a male professor, i.e. his respectability face, and features of his identity face (role of responsibility in the department, professorship category, professional competence and assertiveness, among other attributes), his word was taken with the power of authority by his female colleagues, who chose not to push any further with their proposal. His gender identity face drew on attributes of both respectability face and identity face for its construction. Such attributes seem to have had a strong degree of saliency and, therefore, the power to influence the behavioural expectations by the other interactants, who, on the basis of previous encounters in a similar context, preferred not to push any further.

The behavioural expectations by the female teacher in the extract were, most probably, to find her colleagues' support in both trouble sharing and in the acceptance of her proposal. This hypothesis is based on the fact that support for trouble sharing and acceptance of a proposal are the preferred seconds for a first pair part of trouble sharing and proposal, using conversation analytic terms. Hence, the expected behavioural convention did not turn out as desired, which may have led to an assessment of lack of cooperation and impoliteness by the female teacher.

Considering her face sensitivities, it seems quite possible that her respectability and identity faces resulted damaged, with consequences for rapport. Her self-esteem and professional competence were challenged by the lack of both solidarity and appreciation on the part of the male professor. His omission to offer a preferred second part to the first pair parts (of trouble sharing and proposal) failed to meet the expected social and verbal behaviour by his female colleague. Threaten of her face sensitivities could also lead to tension and judgement of lack of cooperation and impoliteness,

Feminismo/s 38, July 2021, 203-229 
especially if there is an interpersonal crisis among them. Otherwise, the female teacher may have ignored the episode and this may have had few consequences.

Regarding interactional wants, the male colleague is seen to give priority to the transactional, going direct to the point and expressing his opinion while neglecting the relational needs of his female colleague, who was looking for support and reinforcement. In terms of rapport, we can characterize the professor's behaviour as rapport threatening, in Spencer-Oatey's terms.

In the following fragment, the same male speaker who has been portrayed in extract 1 shows alignment with one of the female colleagues in the previous interaction.

\section{Extract 2.}

Male teacher: Recibido. Me parece bien. Muchas gracias, María.

I've got it. It seems OK. Thanks so much, Mary.

Female teacher: Estupendo.

Great.

The male speaker in the former extract acknowledges receipt of a document and agrees with its content. In this particular interaction, neither the male teacher's gender face nor his identity face seem to be challenged by the alignment with his female colleague, so he proceeds to agree and rapport is not damaged.

Extract 3 contrasts with extract 1 and presents a very different gender construction of a male professor, featuring the same attributes as speaker above, who addresses a female lecturer by mail. They participate in a research project and he has submitted a report with several typos and mistakes. She notes the mistakes and asks for their correction:

\section{Extract 3.}

Male: Sí, ya lo sé, soy un desastre pero, por favor, no me eches bronca que esta mañana ya me ha regañado mi mujer.

Yes, I know, I'm a mess but, please, don't tell me off because I've already been told off by my wife this morning.

Female: No te preocupes. Ningún problema. Envíame cuando esté.

Don't worry. No problem. Send me when it's ready.

This male colleague takes responsibility for his mistakes and chooses to beg for his female colleague's understanding, while using a joking tone for doing 
positive politeness, showing closeness and presenting himself in a lower and vulnerable position to his colleague. His respectability identity face scores low in attributes of power or authority and his identity gender face does the same in professional competence and assertiveness. He is open as to his face sensitivities of lack of competence and vulnerability. Regardless of what she may have thought, she orients to his face sensitivities and opts for giving him support, instead of positioning herself in a more powerful and demanding position, which could have damaged his face and been rapport threatening.

His failure to comply to her behavioural expectations could have, otherwise, damaged both her face sensitivities, if understood as lack of support or respect, and his competence face. In this extract, we see that he chooses to compensate for his lack of competence by blaming himself and sharing some details of his private life. By portraying himself as the target of another woman, i.e. his own wife, he manages to avoid face threatening criticism and his identity construction as an incompetent co-worker.

In extract 4, the same man chooses to compensate for his lack of competence by apologizing, adopting a more neutral power stance:

Extract 4.

Male: María, no sé cómo puedo hacer siempre tan mal lo de las xxx. Verás, aquí te envío de nuevo con los cambios. [...] Disculpa, otra vez, por quitarte tanto tiempo.

Mary, I don't know why I'm always making so many mistakes with xxx. Look, I'm sending again with changes. (...) Sorry, again, for wasting so much of your time.

As the first four examples include hetero males, the fifth one illustrates interaction between a female and a non-hetero male colleague, who can also be characterized by attributes of power, authority, professional competence, assertiveness and individualism, in a higher degree than his female colleagues in the interaction. He had suggested participation in a conference to a group of four female colleagues and, after their acceptance, he undertook the role of organizer for a conference panel. One of his female colleagues was not sure whether this meant that they would not be submitting a proposal to a different conference or whether his intention was to have the team attending both conferences. She asks him for confirmation with this mail message: 


\section{Extract 5.}

Female: ¿No hay edición del internacional este año? Supongo que, de haberlo, también sería online ¿Queréis que les preguntemos o preferís participar en éste? ¿O en los dos?

Isn't there an edition for the international conference this year? I guess in case there is it would be online as well. Shall we ask them or do you prefer to participate in this one? Or in both of them?

Male: EN LOS DOS, MI AMOR!!! (...) OS HACE?

IN BOTH OF THEM, MY LOVE!!! (...) IS IT FINE FOR YOU?

As a reply to her question whether they would participate in both conferences, he chose to use a brief and direct assertion that includes the addressing term of endearment «my love». While a hetero male would probably reserve the use of this term for addressing a female in a romantic/sex relationship with him, non-hetero men seem more at ease when using such terms of endearment for addressing female friends or colleagues. This instance illustrates a face-enhancing and safe use of affective language by non-hetero men in interaction with women. Feeling free from association with a flirtatious intention, they can express connection and rapport by making use of positive politeness, including the use of terms of endearment and strategies showing cooperation and reciprocity. The question «iOs hace?» is colloquial and short for a more conventional «iOs parece bien?», which would also feature as positive politeness of closeness and contribute to rapport.

Expected behaviours, face sensitivities and interactional wants seem to be satisfactory for both parts. The female's question « $\mathrm{i}$ en los dos?» (Or in both of them?) is an elicitation for confirmation of the intention by the group leader to have the team participate in two conferences. The affirmative reply entails that he wants them to participate in both of them. Instead of choosing gender practices that reinforced his authority, such as the use of bald on record directive or negative politeness strategies, he chose positive politeness, fulfilling his colleague's expectation to have a reply that enhanced her face and encouraged commitment in the enterprise of participating in the two upcoming conferences. He could have chosen to position himself in a higher position, by building a respectability face of authority together with an identity face of power due to his coordinator role. Quite the contrary, he chose to position himself on a par and enhance rapport. 
In another interaction, the same male portrayed in the previous extract chooses to build a more distant stance:

Extract 6.

Male: María, por favor, vamos a volver a ir al congreso de xxx. Por favor, ¿puedes volver a hacer la propuesta de gasto...? Mismos datos que año pasado. Mil gracias.

Mary, please, we are attending the same conference xxx. Please, could you submit the expense proposal again? Same details as last year. Thanks a million.

In this case, the speaker opts for negative politeness, showing deference and respect with the use of the politeness marker "please» and the modal «could». As a term of address, the speaker chooses the addressee's first name without any terms of endearment. This fragment results in the construction of identity and respectability faces in line with the attributes of power, authority, professional competence, assertiveness and individualism. The need for building camaraderie or closer rapport is not salient in this interaction and, therefore, the speaker relies on transactional talk for efficiency.

One last example portrays another gay male who opts for using affective language with a female colleague. After having received several documents upon request, Martin replies:

\section{Extract 7.}

Female: Here you are Martin!

Male: You are my hero of the day, schatzi-:

This gay male speaker, who ranks high in respectability and identity faces, featuring similar attributes of power to those upheld by male speakers in former extracts, uses face-enhancing positive politeness, upgrading his addressee to the level of a hero and showing affection by use of a term of endearment in his native German language and an emoticon.

Despite limited space prevents from a more extensive analysis of a wider sample, I hope these extracts serve to illustrate the different resources deployed by hetero and gay male speakers in their interaction with female colleagues. The language used in extracts 5 and 7 rate high in face-enhancing positive politeness and rapport. It seems it would be difficult to understand this language in utterances by hetero professors, without further 
implications of a romantic/sex relationship with the addressee or intentions for such, at least.

\section{CONCLUDING REMARKS}

This article is intended as a contribution to research within the third-wave of sociolinguistic studies in the exploration of gender practices in interaction, considering the management of social relations by hetero and non-hetero individuals. The concepts of face, identity, rapport and (im)politeness have been reviewed and applied to the analysis of several extracts from authentic interactive sequences, attempting to show their potential in our understanding of the construction of gender identity from a discursive approach. The sample includes hetero and gay male professors of the same age band in interaction with female lecturers, a lower rank in the academic scale.

It is argued that gender identity face builds on attributes of both respectability and identity faces for the construction of hetero and non-hetero gender identities, with differing strengths or saliency depending on the individuals and the context. While hetero males are seen to use different gender identity patterns in a continuum of power, exercising freedom to choose from very high to subservient positions, gay males show a tendency to enhance rapport and to use face-enhancing positive politeness for bonding with their female colleagues, freer from suspicions of flirtatious behaviour.

The analysis of seven extracts from authentic interaction shows that gender identity, face, rapport and impoliteness are elements that are worked out within the course of interaction, instead of stable a priori categories. Interactants build their gender identities through their gender practices. Their linguistic behaviours may, or may not, be in line with gender stereotypes but will, nevertheless, express how interactants choose to position themselves. Whether they show power or not, express rapport or distance and different identity attributes, their gender practices perform their gender identity. 


\section{REFERENCES}

Beebe, L. M. (1995). Polite fictions: Instrumental rudeness as pragmatic competence. In J. E. Alatis, C. A. Straehle, B. Gallenberger, \& M. Ronkin (Eds.) Linguistics and the education of language teachers: Ethnolinguistic, psycholinguistics and sociolinguistic aspects. Georgetown University Round Table on Languages and Linguistics (pp. 154-168). Georgetown University Press.

Bousfield, D. (2008). Impoliteness in interaction. John Benjamins. https://doi. org/10.1075/pbns.167

Brown, P., \& Levinson, S. (1987). Politeness: Some Universals in Language Usage. Cambridge University Press. https://doi.org/10.1017/CBO9780511813085

Butler, J. (1990). Gender trouble: Feminism and the subversion of identity. Routledge. https://doi.org/10.4324/9780203824979

Chafe, W. (1994). Discourse, consciousness, and time: The flow and displacement of conscious experience in speaking and writing. University of Chicago Press.

Dippold, D. (2009). Face and self-presentation in spoken L2 discourse: Renewing the research agenda in interlanguage pragmatics. Intercultural Pragmatics, 6(1), 1-28. Walter de Gruyter. https://doi.org/10.1515/IPRG.2009.001

Eckert, P. (2012). Three waves of variation study: The emergence of meaning in the study of variation. Annual Review of Anthropology, 41. 87-100. https:// doi.org/10.1146/annurev-anthro-092611-145828

Eckert, P. (2019). The limits of meaning: Social indexicality, variation, and the cline of interiority. Language, 95(4). 751-776. https://doi.org/10.1353/ lan.2019.0072

Eckert, P., \& McConnell-Ginet S. (2003). Language and gender. Cambridge University Press. https://doi.org/10.1017/CBO9780511791147

Garcés-Conejos Blitvich, P., \& Sifianou, M. (2017). (Im)politeness and identity. In J. Culpeper, Haugh, M., \& Kádár D. Z. (Eds.) The Palgrave handbook of linguistic (Im)politeness (pp. 227-256). Palgrave Macmillan. https://doi. org/10.1057/978-1-137-37508-7

Goffman, E. (1967). Interaction ritual: Essays on face to face behavior. Doubleday. Grainger, K., \& Mills, S. (2016). Directness and indirectness across cultures. Palgrave Macmillan. https://doi.org/10.1057/9781137340399

Ho, D. Y. F. (1994). Face dynamics: From conceptualization to measurement. In S. Ting-Toomey (Ed.) The challenge of facework (pp. 269-286). State University of New York Press. 
House, J. (2018). Authentic vs elicited data and qualitative vs quantitative research methods in pragmatics: Overcoming two non-fruitful dichotomies. System, 75, 4-12. https://doi.org/10.1016/j.system.2018.03.014

Kádár, D. Z., \& Haugh M. (2013). Understanding politeness. Cambridge University Press. https://doi.org/10.1017/CBO9781139382717

Mahdawi, A. (2016). 'Who's the man?' Why the gender divide in same-sex relationships is a farce. The Guardian. https://www.theguardian.com/ lifeandstyle/2016/aug/23/same-sex-relationship-gender-roles-chores

Markus, H. R., \& Kitayama S. (1991). Culture and the self: Implications for cognition, emotion, and motivation. Psychological Review, 98(2): 224-253. https://doi.org/10.1037/0033-295X.98.2.224

Matsumoto, Y. (1988). Reexamination of the universality of face: politeness phenomena in Japanese. Journal of Pragmatics, 12, 403-426. https://doi. org/10.1016/0378-2166(88)90003-3

McElhinny, B. (1998). 'I don't smile much any more': Affect, gender and the discourse of Pittsburgh Police Officers. In J. Coates (Ed.) Language and gender: A Reader (pp. 309-327). Blackwell.

Mills, S. (2003). Gender and politeness. Cambridge: Cambridge University Press. https://doi.org/10.1017/CBO9780511615238

Mills, S. (2005). Gender and impoliteness. Journal of Politeness Research. Language, Behaviour, Culture, 1(2), 263-280. https://doi.org/10.1515/jplr.2005.1.2.263

O’Driscoll, J. (2017). Face and (im)politeness. In J. Culpeper, M. Haugh, \& D. Kádár (Eds.), The Palgrave handbook of linguistic (im)politeness, (pp. 89-118). Palgrave Macmillan. https://doi.org/10.1057/978-1-137-37508-7

Partington, A., Duguid, A., \& Taylor, C. (2013). Patterns and meanings in discourse: Theory and practice in corpus-assisted discourse studies. John Benjamins. https://doi.org/10.1075/scl.55

Peräkylä, A. (2004). Two traditions of interaction research. British Journal of Social Psychology, 43(1), 1-20. https://doi.org/10.1348/014466604322915953

Scott, J. C. (1990). Domination and the arts of resistance: Hidden transcripts. Yale University Press.

Simon, B. (2004). Identity in modern society. A social psychological perspective. Blackwell. https://doi.org/10.1002/9780470773437

Spencer-Oatey, H. (2005). (Im) Politeness, face and perceptions of rapport: unpackaging their bases and interrelationships. Journal of politeness 
research. Language, behaviour, culture, 1(1), 95-119. https://doi.org/10.1515/ jplr.2005.1.1.95

Spencer-Oatey, H. (2007). Theories of identity and the analysis of face. Journal of pragmatics, 39(4), 639-656. https://doi.org/10.1016/j.pragma.2006.12.004

Terkourafi, M. (2008). Toward a unified theory of politeness, impoliteness and rudeness. In D. Bousfield, \& M. Locher (Eds.) Impoliteness in Language: Studies on Its Interplay with Power in Theory and Practice, (pp. 45-74). Mouton de Gruyter.

Thomas, J. (1995). Meaning in interaction. Longman.

Van der Bom, I., \& Mills, S. (2015). A discursive approach to the analysis of politeness data. Journal of politeness research. Language, behaviour, culture, 11(2), 179-206. https://doi.org/10.1515/pr-2015-0008 